\title{
Sistem Informasi Kepegawaian Berbasis Website Pada PT Sumatera Panca Rajo Palembang
}

\author{
Ega Dwisaputra Nurmawan*1, Mulyati, S.E.,M.T.I. ${ }^{2}$ \\ ${ }^{1,2}$ STMIK GI MDP; Jl. Rajawali No.14 Palembang, Telp: (0711) 376400 \\ Program Studi Sistem Informasi, STMIK GI MDP, Palembang \\ e-mail: *11egadwisaputranurmawan@mhs.mdp.ac.id, ${ }^{2}$ muliati@mdp.ac.id
}

\begin{abstract}
Abstrak
Sistem informasi saat ini merupakan hal yang sangat dibutuhkan oleh semua bentuk bisnis. Hal ini berdampak pada perkembangan teknologi yang signifikan, sehingga perusahaan berlomba-lomba untuk memberikan pelayanan yang terbaik dengan cara peningkatan menggunakan bantuan teknologi dan sistem informasi. Dalam kegiatan operasional sehari-hari PT. Sumatera Panca Rajo saat ini hanya menggunakan aplikasi perkantoran biasa belum menerapkan sistem kepegawaian, hal ini membuat sulitnya dalam melakukan perekapan data absensi dan lembur karena masih menggunakan kertas yang disimpan didalam folder, sehingga rentan mengalami kehilangan dan kerusakan. Untuk melakukan perekapan data absensi dan lembur, biasanya bagian operasional harus mencari arsip data yang tersimpan terlebih dahulu. Karena itulah manajemen PT. Sumatera Panca Rajo kesulitan untuk mengontrol, dan mengevaluasi kinerja pegawainya, masalah ini dirasa menghambat kinerja perusahaan. Berdasarkan uraian tersebut penulis mencoba membantu menyelesaikan permasalahan dengan membuatkan Sistem Informasi Kepegawaian Berbasis Website Pada PT. Sumatera Panca Rajo. Dalam pengembangan sistem informasi ini penulis menggunakan pengembangan prangkat lunak Iterasi, untuk menganalisis permasalahan penulis menggunakan alur analisis PIECES, mengumpulkan data melalui observasi, wawancara, dan studi pustaka. Merancang perangkat lunak menggunakan permodelan UML. Dengan dibangunnya sistem informasi ini PT. Sumatera Panca Rajo dapat memperoleh informasi mengenai kehadiran, data-data pegawai, mutasi, pemberhentian pegawai, dan perekrutan pegawai, serta dapat melakukan penilaian terhadap kinerja pegawainya.
\end{abstract}

Kata kunci: Website, Kepegawaian, Iterasi, PIECES, UML

\begin{abstract}
The current information system is something that is needed by all forms of business. This has an impact on significant technological developments, so companies are competing to provide the best service by increasing the use of technology and information systems. In the daily operations of PT. Sumatra Panca Rajo currently only uses ordinary office applications yet to implement a staffing system, this makes it difficult to perform absenteeism and overtime data recapitulation because it still uses paper stored in folders, making it vulnerable to loss and damage. To do attendance data recording and overtime, usually the operational part must look for archived data first. That's why the management of PT. Sumatra Panca Rajo has difficulty controlling, and evaluating the performance of its employees, this problem is perceived as hampering the company's performance. Based on the description, the author tries to help solve the problem by creating a Website Based Personnel Information System at PT. Sumatra Panca Rajo. In developing this information system the author uses the development of Iteration software, to analyze the problem the author uses the PIECES analysis flow, collecting data through observation, interviews, and literature. Designing software using UML modeling. With
\end{abstract}


the construction of this information system PT. Sumatra Panca Rajo can obtain information about attendance, employee data, transfer, employee dismissal, and employee recruitment, and can evaluate the performance of its employees.

Keywords: Website, Staffing, Iteration, PIECES, UML

\section{PENDAHULUAN}

Sistem informasi saat ini merupakan hal yang sangat dibutuhkan oleh semua bentuk bisnis. Hal ini berdampak pada perkembangan teknologi yang sangat signifikan, sehingga perusahaan berlomba-lomba untuk memberikan pelayanan terbaik dengan cara melakukan peningkatan menggunakan bantuan teknologi dan sistem informasi. Dengan adanya teknologi informasi juga dapat mempengaruhi kinerja di perusahaan dalam kegiatan operasional, karena itulah sistem informasi sangat penting bagi perusahaan khususnya pada perusahaan jasa.

Dalam kegiatan operasional sehari-hari perusahaan ini hanya menggunakan aplikasi perkantoran biasa dan belum menerapkan sistem kepegawaian, hal ini membuat sulitnya dalam melakukan perekapan data absensi dan lembur karena data absensi dan lembur pegawai masih menggunakan kertas yang disimpan didalam folder, sehingga rentan mengalami kehilangan dan kerusakan. Untuk melakukan perekapan data absensi dan lembur, biasanya bagian operasional harus mencari arsip data yang tersimpan terlebih dahulu, dengan lamanya proses perekapan data absensi dan lembur, maka akan mengalami kesulitan dalam mengontrol, dan mengevaluasi kinerja pegawainya, masalah ini dirasa menghambat kinerja perusahaan. Kegiatan rekrutmen yang dilakukan juga akan memakan biaya dan waktu yang lama, hal ini disebabkan belum adanya website sebagai tempat informasi bagi pelamar dan sulitnya dalam melakukan seleksi berkas lamaran yang dikirimkan oleh calon pegawai baru, sehingga memerlukan waktu yang lama untuk mengumumkan hasil seleksi.

Berdasarkan uraian latar belakang diatas maka dibangun sebuah aplikasi membantu menyelesaikan permasalahan yang ada pada PT. Sumatera Panca Rajo dengan yaitu "Sistem Informasi Kepegawaian Berbasis Website Pada PT. Sumatera Panca Rajo Palembang”.

\section{METODE PENELITIAN}

Dalam membangun aplikasi menggunakan Metodologi Iteratif. Metodologi Iteratif (Iterative Model) mengkombinasikan proses-proses pada model air terjun dan iteratif pada model prototipe yang menghasilkan versi-versi perangkat lunak yang sudah mengalami pertambahanya. Model ini cocok untuk pengembangan dengan Turn Over yang tinggi [1]. Dalam Metodologi Iteratif ini terdapat beberapa tahapan yaitu:

1. Tahap Perencanaan

Pada tahap Perencanaan ini, hal yang dilakukan adalah mengamati sistem dan bisnis pada PT. Sumatera Panca Rajo untuk menentukan ruang lingkup sistem yang akan dibangun dan mengumpulkan data yang akan dibutuhkan.

2. Tahap Analisis

Pada tahap ini, data-data yang telah berhasil dikumpulkan akan dilakukan analisis dengan menggunakan tools berupa PIECES untuk mengetahui masalah yang terjadi sehingga kebutuhan dapat di gambarkan dengan menggunakan Diagram Use Case. 
3. Tahap Perancangan

Pada tahap ini, penulis memberikan rancangan mengenai gambaran aplikasi yang akan dibuat dan bagaimana tampilan user interface pada aplikasi. Ditahap ini juga akan dilakukan perancangan atau desain baik tampilan aplikasi, pembuatan coding, dan perancanagan arsitektur.

4. Tahap Tes/Implementasi

Pada tahap ini, penulis melakukan penggujian aplikasi yang telah dibuat untuk mengatasi permasalahan yang ditemukan setelah melakukan kegiatan analisis sebelumnya, dengan memastikan semua bagian telah dilakukan pengujian. Hal ini dilakukan untuk meminalisir kesalahan (error) dan memastikan aplikasi bekerja dengan baik.

\subsection{Sistem Informasi}

Sistem informasi adalah suatu sistem pada organisasi yang mempertemukan kebutuhan transaksi harian, mendukung operasi, bersifat majerial, dan merupakan kegiatan strategi dari suatu organisasi, serta menyediakan laporan-laporan yang diperlukan oleh pihak luar [6].

\subsection{Sistem Informasi Manajemen}

Sistem Informasi Manajemen merupakan kumpulan dari sub-sub sistem yang saling berhubungan satu sama lain dan bekerja sama secara harmonis untuk mencapai satu tujuan yaitu mengolah data menjadi informasi yang diperlukan oleh manajemen dalam proses pengambilan keputusan saat melaksanakan fungsinya [12].

\subsection{Kepegawaian}

Kepegawaian merupakan kekayaan utama suatu perusahaan, karena tanpa keikutsertaan mereka, aktivitas tidak akan terjadi. Karyawan berperan aktif dalam menetapkan rencana, sistem, proses, dan tujuan yang ingin dicapai [4].

\subsection{Sistem Informasi Manajemen Kepegawaian}

Sistem Informasi Manajemen Kepegawaian merupakan prosedur sistematik untuk mengumpulkan, menyimpan, mempertahankan, menarik, dan memvalidasi data yang dibutuhkan oleh sebuah organisasi tentang sumber daya manusia, karakteristik-karakteristik unit-unit organisasi [11].

\subsection{Sistem Informasi Sumberdaya Manusia}

Sistem Informasi Sumberdaya Manusia adalah suatu prosedur sistematik pengumpulan, penyimpanan, pemeliharaan, perolehan kembali dan validasi berbagai data tertentu yang dibutuhkan oleh suatu organisasi tentang sumberdaya manusianya, kegiatan-kegiatan personalia dan karakteristik-karakteristik satuan kerja [3].

\subsection{Outsourcing}

Outsourcing adalah suatu perjanjian dimana pemborong mengikatkan diri untuk membuat suatu kerja tertentu bagi pihak lain yang memborongkan pekerjaan kepada pihak pemborongan dengan bayaran tertentu [7].

\subsection{Website}

Website adalah sebuah sistem dengan adanya informasi dalam bentuk teks, gambar, suara, dan lain-lain yang tersimpan dalam server web internet untuk ditampilkan dalam bantuk hiperteks [10]. 


\section{$2.8 \quad H T M L$}

HTML adalah bahasa yang menggunakan perintah sederhana dalam standar dokumen teks ASCII untuk menyediakan suatu tampilan visual yang terintegrasi [5].

\section{$2.9 \quad M y S Q L$}

MySQL adalah perangkat lunak basis data yang paling populer di kalangan Linux dan Windows. Mempunyai performansi query dari basis data yang paling cepat dan jarang bermasalah [9].

\subsection{PHP}

PHP adalah singkatan dari PHP Hypertext Preprocessor yang digunakan sebagai bahasa script server-side dalam pengembangan Web yang dimasuklan ke dalam dokumen HTML [8].

\subsection{PIECES}

PIECES adalah sebuah alat untuk melakukan analisis permasalahan utama yang meliputi Performance, Information, Economy, Control, Efficiency, dan Service [2]. Manfaat melakukan analisis PIECES adalah dapat ditemukannya permasalahan dari prosedur sistem yang berjalan, sehingga dapat ditemukan solusi dari permasalahan tersebut.

\section{HASIL DAN PEMBAHASAN}

\subsection{Analisis Permasalahan}

Setelah dilakukan Observasi, penulis melakukan analisis terhadap permasalahan yang terjadi pada PT. Sumatera Panca Rajo Palembang. Penulis melakukan analisis permasalahan dengan menggunakan kerangka Performance, Information, Economics, Control, Efficiency, Service (PIECES). Adapun permasalahan yang di identifikasi penulis adalah sebagai berikut

Tabel 1. Analisis Permasalahan Kerangka PIECES

\begin{tabular}{|c|c|}
\hline PIECES & Permasalahan \\
\hline Performance & $\begin{array}{l}\text { Proses seleksi calon pegawai baru masih membutuhkan } \\
\text { waktu yang lama. }\end{array}$ \\
\hline Information & $\begin{array}{l}\text { - Bagian Operasional harus mengkonfirmasi kepada pegawai } \\
\text { mengenai Absen dan Lembur. }\end{array}$ \\
\hline Econc & $\begin{array}{l}\text { Proses seleksi pegawai baru membutuhkan banyak pegawai } \\
\text { untuk menjadi tim seleksi. }\end{array}$ \\
\hline Cont & Kesulitan untuk melakukan penilaian pegawai. \\
\hline Efficiency & sering mengalami rekap per \\
\hline Service & Sering mendapatkan komplain dari pegawai. \\
\hline
\end{tabular}

\subsection{Analisis Kebutuhan}

Gambar 1 untuk menganalisis kebutuhan dari sistem yang akan akan dikembangkan dari kebutuhan yang telah didapatkan. Dalam melakukan analisis kebutuhan sistem, penulis menggunakan alat bantu diagram Use Case. Penggunaan diagram Use Case ini diharapkan dapat menganalisis model kebutuhan dari pengguna, bagaimana sistem ini dibangun dan iimplementasikan. 


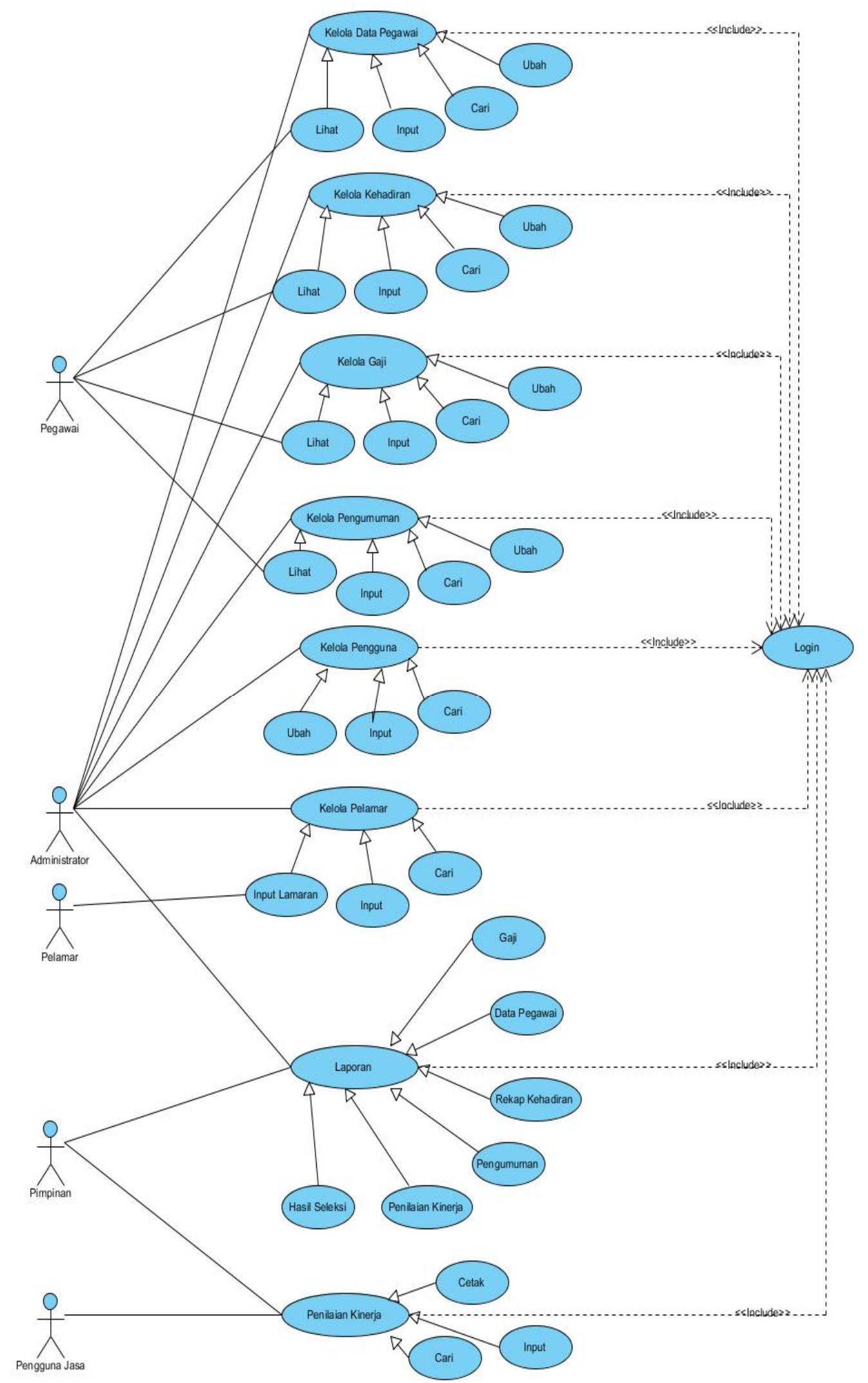

Gambar 1. Diagram Use Case 


\subsection{Rancangan Sistem}

\subsubsection{Diagram Konteks}

Diagram Konteks adalah DFD pertama dalam rancangan proses bisnis. Diagram Konteks menunjukan sebuah proses inti yang menggambarkan satu lingkaran besar yang mewakili seluruh proses sistem yang terhubung ke semua entitas untuk menerima atau memberikan informasi ke sistem.

Berdasarkan gambar 2 rancangan sistem terdiri dari lima entitas yaitu Pegawai, Administrator, Pimpinan, Pengguna Jasa, dan Pelamar. Semua aliran entitas menuju proses sistem yang ada. Diagaram Konteks dapat dilihat pada gambar 2.

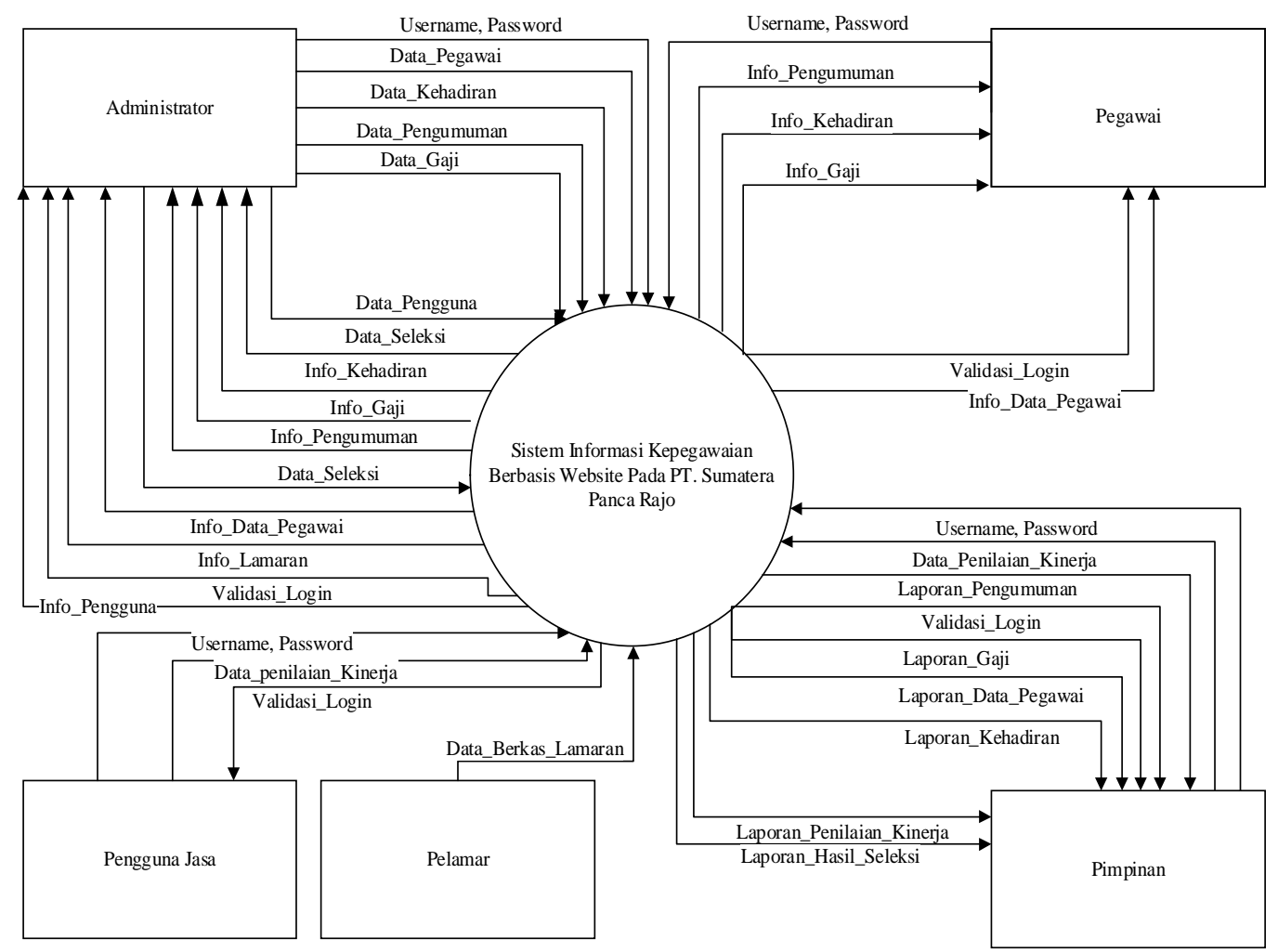

Gambar 2. Diagram Konteks

\subsubsection{Diagram Dekomposisi}

Diagram Dekomposisi adalah pengambaran diagram yang digunakan untuk menguraikan sistem menjadi sub sistem, proses, dan sub proses.

Berdasarkan Gambar 3 terlihat rancangan sistem terdapat sembilan sub sistem yaitu Login, Data Pegawai, Kehadiran, Gaji, Pengguna, Pengumuman, Pelamar, Laporan, dan Penilaian Kinerja. Diagram Dekomposisi dapat dilihat pada Gambar 3 


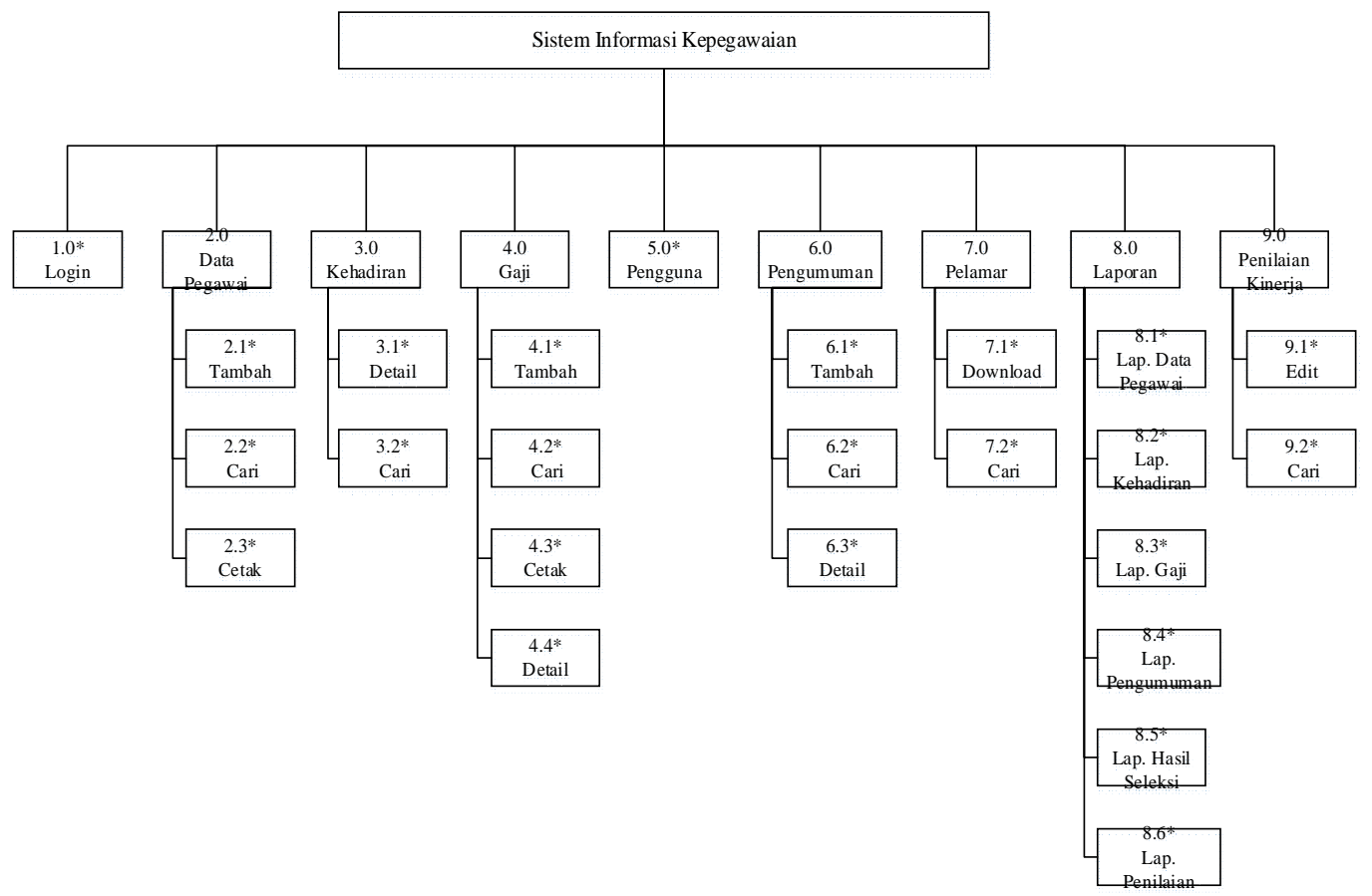

Gambar 3. Diagram Dekomposisi

\subsubsection{Data Flow Diagram}

Data Flow Diagram (DFD) merupakan pengambaran dekomposisi dari diagram konteks. DFD menunjukan keseluruhan sistem yang memiliki aliran data masuk dan aliran data keluar.

Berdasarkan Gambar 4 terlihat rancangan sistem terdapat duabelas sub sistem yaitu sembilan sub sistem yaitu Login, Data Pegawai, Kehadiran, Gaji, Pengguna, Pengumuman, Pelamar, Laporan, dan Penilaian Kinerja. Dimana pada setiap proses memiliki aliran data yang masing-masing memiliki fungsi dan penjelasan khusus terhadap proses sistem yang berjalan. Data Flow Diagram (DFD) dapat dilihat pada Gambar 4 


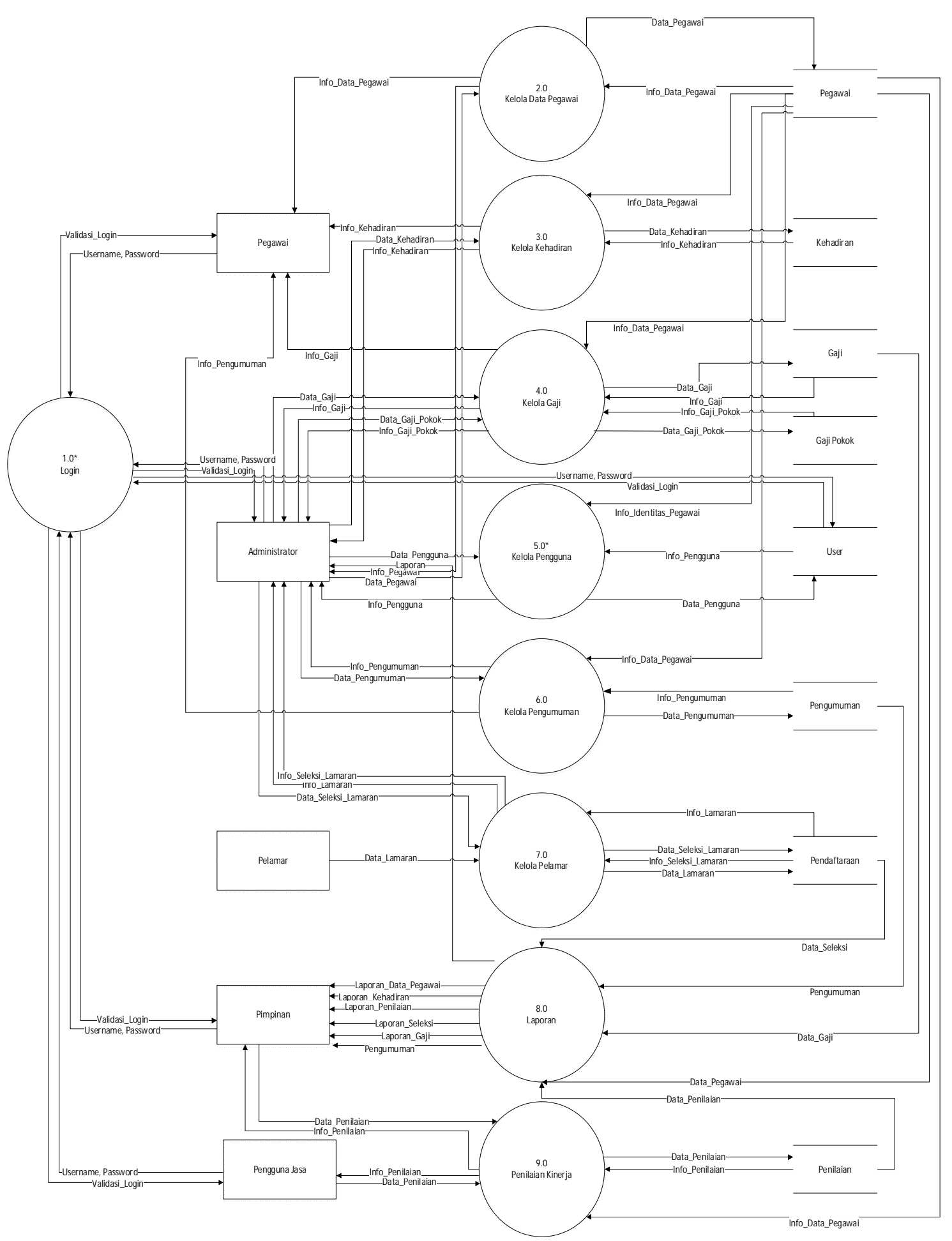

Gambar 4. Data Flow Diagaram (DFD)

\subsubsection{Entity Relationship Diagram (ERD)}

Entity Relationship Diagram (ERD) ini menggunakan Versi yang dikembangkan oleh Chen. ERD dapat dilihat pada Gambar 5 


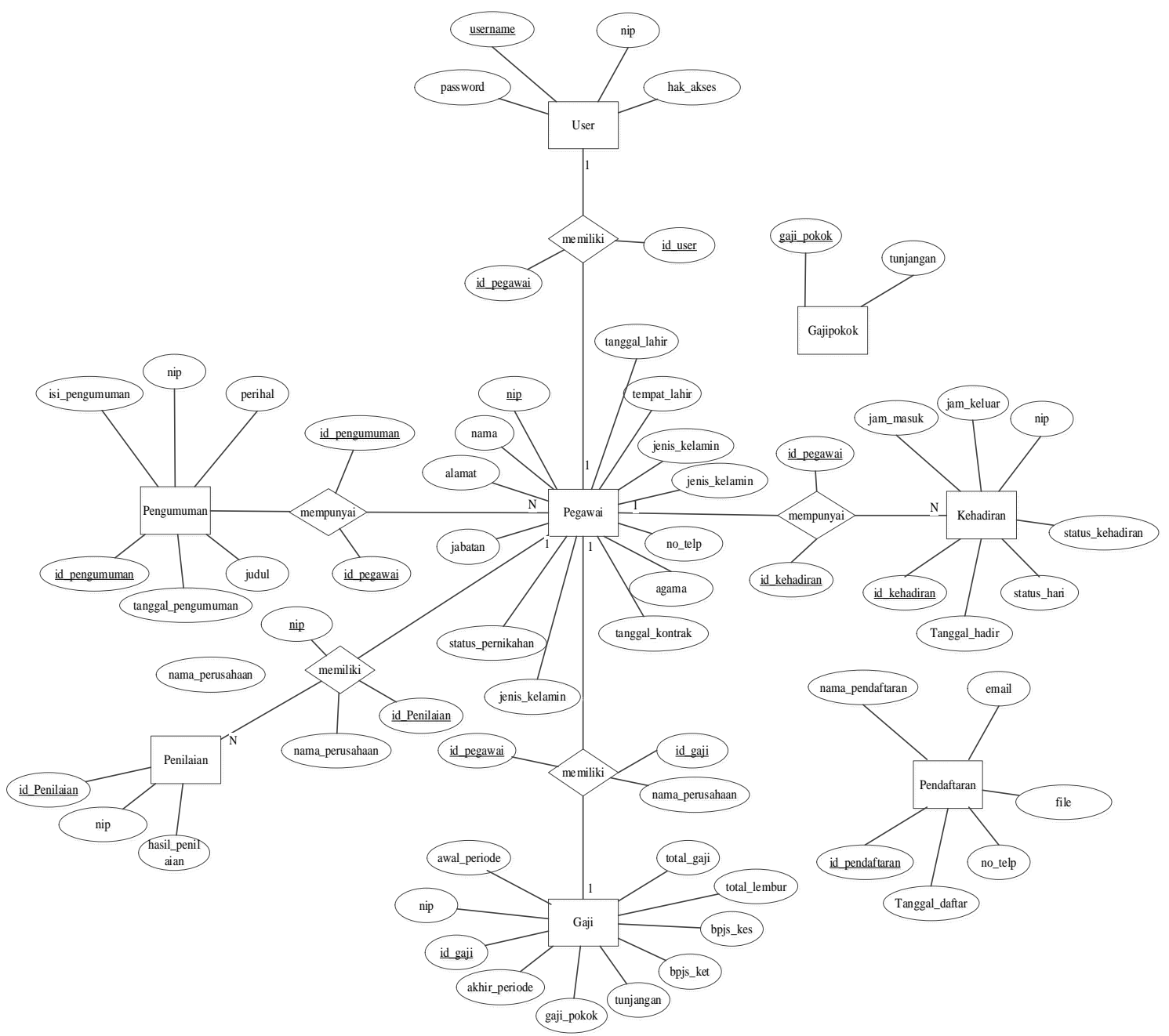

Gambar 5. Entity Relationship Diagram

\subsubsection{Rancangan Antarmuka}

Tampilan halaman awal ini dapat diakses oleh siapa saja, dimana didalam tampilan halaman awal ini menampilkan semua berita mengenai perusahaan PT. Sumatera Panca Rajo. 


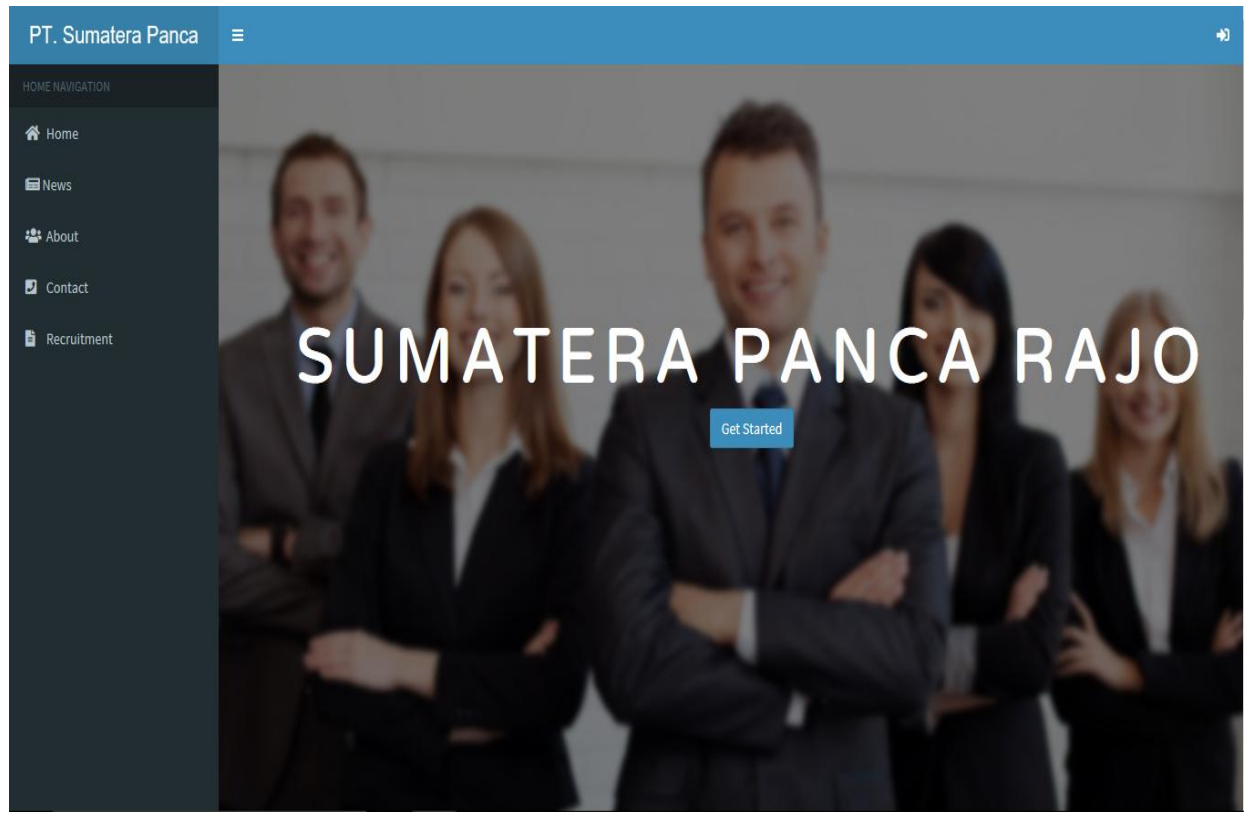

Gambar 6. Tampilan Halaman Awal

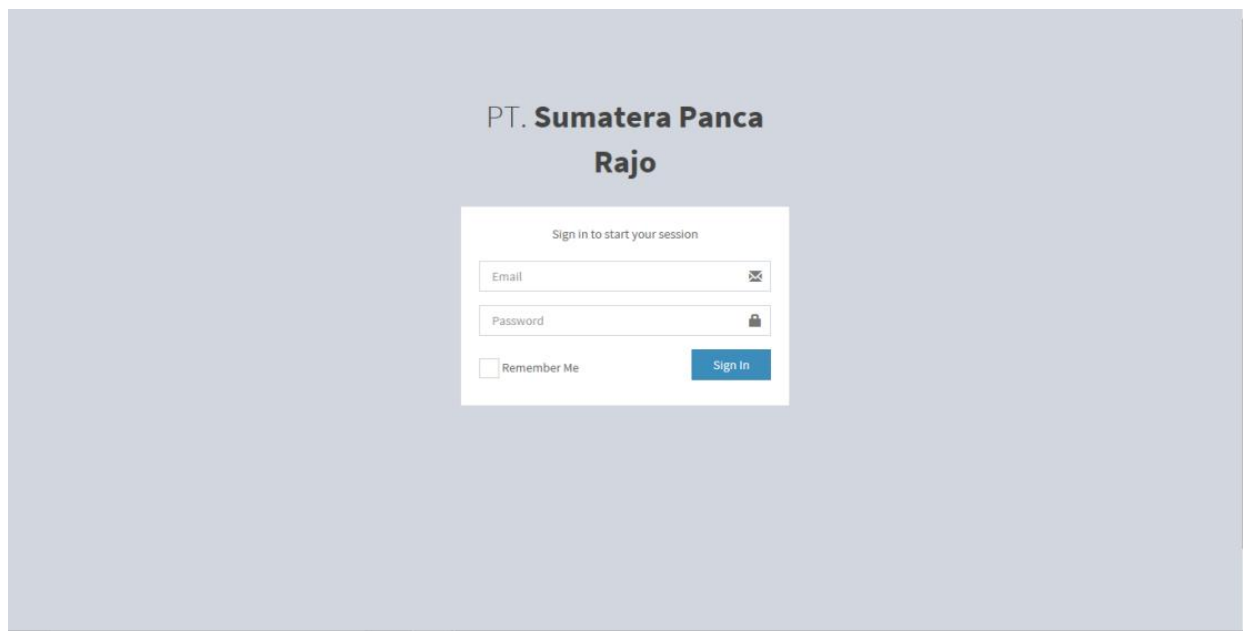

Gambar 7. Tampilan Halaman Login

\section{KESIMPULAN}

Dengan dibangunnya "Sistem Informasi Kepegawaian Berbasis Website Pada PT. Sumatera Panca Rajo Palembang” dapat ditarik kesimpulan sebagai berikut:

1. Sistem Informasi Kepegawaian mempermudah dalam proses Rekrutmen dan Seleksi calon Pegawai baru.

2. Sistem Informasi Kepegawaian mempermudah Pegawai dalam melihat Data Pegawai, Kehadiran, Gaji, Pengumuman.

3. Sistem Informasi Kepegawaian mempermudah Manajemen dalam proses rekap Absen dan Lembur Pegawai.

4. Dengan adanya Sistem Informasi Kepegawaian mempermudah Manajemen dan Pengguna Jasa untuk melakukan Penilaian Kinerja Pegawai.

Nurmawan, et, al (Sistem Informasi Kepegawaian Berbasis Website Pada PT. Sumatera Panca Rajo Palembang) 


\section{SARAN}

Berdasarkan hasil analisa yang telah dilakukan, ada beberapa saran yang dapat diberikan terkait hal yang akan membantu dalam pengembangan Sistem Informasi Kepegawaian ini agar kedepannya lebih baik lagi.

1. Perlunya dilakukan Maintenance secara berkala.

2. Perlunya pengembangan sistem untuk menyesuaikan teknologi informasi yang semakin berkembang.

\section{DAFTAR PUSTAKA}

[1] A.S, Rosa dan Salahuddin, M 2013, Rekayasa Perangkat Lunak, Informatika, Bandung.

[2] Fatta, HA 2007, Analisis dan Perancangan Sistem Informasi, Andi Offset, Yogyakarta.

[3] Handoko, T. Hani 2011, Manajemen Personalia \& SDM Edisi-2, BPFE, Yogyakarta.

[4] Hasibuan, Malayu S.P. 2009, Manajemen: Dasar, Pengertian, dan Masalah Edisi Revisi, Bumi Aksara, Jakarta.

[5] Komputer, Wahana 2006, Panduan Lengkap Menguasai Pemrograman Web dengan PHP 5, Andi Offset, Yogyakarta.

[6] Kusrini 2007, Konsep dan Aplkasi Sistem Pendukung Keputusan, Andi Offset, Yogyakarta.

[7] Nedeng, I Wayan 2003, Outsourcing dan PKWT, PT. Lembangtek, Jakarta

[8] Peranginangin, Kasiman 2006, Aplikasi Web dengan PHP dan MySQL, Andi Offset, Yogyakarta.

[9] Pohan, Husni I dan Sidik, Betha 2012, Pemrograman Web dengan HTML, Informatika, Bandung.

[10] Simarmata, Janner 2009, Rekayasa Web, Andi Offset, Yogyakarta.

[11] Simamora, Henry 2001, Manajemen Sumber Daya Manusia, STIE YKPN, Yogyakarta.

[12] Susanto, Azhar 2016, Sistem Informasi Manajemen: Konsep dan Pengembangan Secara Terpadu, Lingga Jaya, Bandung 